\title{
PERBANDINGAN SARI KACANG KEDELAI DENGAN BUBUR UMBI BIT DAN KONSENTRASI SANTAN TERHADAP KARAKTERISTIK ES KRIM NABATI
}

\author{
Nana Sutisna Achyadi, Hervelly, Hanny Respiani \\ Program Studi Teknologi Pangan, Fakultas Teknik, Universitas Pasundan, Jl. Dr.Setiabudi No 193, Bandung, 40153, \\ Indonesia
}

Email : nanasutisnaachyadi@unpas.ac.id

\begin{abstract}
The purpose of this study was to determine the comparison of soybean milk with beetroot extract and concentrate of coconut milk on the characteristics of vegetable ice cream. This research method was conducted in two stages, namely preliminary research consist of analysis of total dissolved solids from the ratio of soybeans to water, namely (1:4), (1: 6) and (1: 8). The primary research was carried out by using a 3x3 factorial system of randomized block design (RBD)/ Rancangan Acak Kelompok (RAK) with three repetitions. Factor (A) was comparison of soybean juice with beetroot porridge, consisting of 3 (three) levels a1 $=1: 1, \mathrm{a} 2=1: 2, \mathrm{a} 3=2: 1$, and factor (B) was the use of coconut milk concentration, consisting of 3 (three ) level $\mathrm{b} 1=18 \%, \mathrm{~b} 2=20 \%$ and $\mathrm{b} 3=22 \%$. The results showed that the comparison of soybean milk with beetroot slurry influences fat content, overrun, melting time, and organoleptic tests including color, aroma and texture. Coconut milk concentration affects organoleptic test of texture attributes. The interaction between soybean juice comparison with beetroot extract and concentration of coconut milk on vegetable ice cream affected the organoleptic test of taste attributes but did not affect the fat content, protein content, overrun, melting time and organoleptic test of the color attributes, aroma and texture. The comparison of soybean juice with beetroot slurry influences fat content, overrun, melting time, and organoleptic tests including color, aroma and texture.
\end{abstract}

Keywords : Beetroot, Coconut milk, Soybean milk, Vegetable Ice Cream.

\section{Pendahuluan}

Es krim adalah salah satu produk makanan beku yang dibuat dengan membekukan produk susu, gula, penstabil, pengemulsi dan bahan-bahan lainnya yang telah dipasteurisasi dan dihomogenisasi sebelumnya untuk memperoleh konsistensi yang seragam (Arbuckle et al, 2000).

Padaga, dkk (2005) menyatakan bahwa es krim adalah produk pangan beku yang dibuat melalui kombinasi proses pembekuan dan agitasi pada bahanbahan yang terdiri dari susu dan produk susu, pemanis, penstabil, pengemulsi, serta penambahan cita rasa. Prinsip pembuatan es krim adalah menangkap udara pada adonan es krim sehingga terjadi pengembangan volume yang membuat es krim menjadi mengembang, tidak terlalu padat, dan mempunyai tekstur yang lembut.

Es krim merupakan hidangan beku yang memiliki kandungan gizi tinggi dan banyak di gemari masyarakat. Konsumen es krim tidak terbatas pada golongan anakanak tetapi sudah meluas dikalangan remaja, dewasa, dan orangtua.

Produk es krim di pasaran sebagian besar menggunakan bahan utama adalah susu sapi. Susu sapi dapat meningkatkan kadar kolestrol sehingga tidak dianjurkan untuk dikonsumsi secara berlebihan, terutama bagi penderita penyakit tertentu dan alergi terhadap protein hewani. Pembuatan es krim dari susu sapi dapat dicampurkan dengan susu nabati salah satunya yaitu susu kedelai. Penambahan susu kedelai ke dalam susu sapi dalam pembuatan es krim, untuk meningkatkan kadar protein es krim yang dihasilkan (Pamungkasari, 2008).

Alasan yang mendasari mengapa dipilih susu kedelai dalam pembuatan es krim adalah susu kedelai memiliki kadar protein dan komposisi asam amino yang hampir sama dengan susu sapi. Selain itu susu kedelai mengandung mineral (kalsium, fosfor dan besi) dan vitamin (vitamin A, vitamin B1 dan vitamin C) dalam jumlah yang cukup. Keunggulan susu kedelai dibanding dengan susu sapi adalah susu kedelai tidak mengandung kolestrol. Susu kedelai di masa depan menjadi makin penting, disebabkan oleh keunggulan yang dimiliki oleh susu kedelai, yaitu tidak mengandung laktosa, rendah lemak, bebas kolestrol, bergizi tinggi, teknologi pembuatannya relatif mudah, biaya produksi relatif murah.

Es krim yang dibuat dari susu kedelai memiliki warna yang kurang menarik sehingga perlu ditambahkan pewarna, salah satu pewarna alami yang dapat digunakan dalam pembuatan es krim adalah sari umbi bit.

Umbi bit merupakan salah satu bahan pangan yang bermanfaat, salah satu manfaat bit adalah memberikan warna alami dalam pembuatan produk pangan. Bit mengandung pigmen betasianin yang bisa berfungsi sebagai pewarna alami. Pigmen warna umbi bit merupakan pewarna alami yang aman untuk dikonsumsi dan telah mendapatkan persetujuan dari Food and Drug Administration (FDA) yang tergolong uncertified color additives (Tjahjadi dalam Widhiana, 2000). Warna merah bit berasal dari pigmen betalain yang memiliki 
gugus nitrogen dengan susunan kimia yang mirip dengan antosianin (Nurianty, 1985).

Umbi bit memiliki ciri spesifik berwarna merah, walaupun berwarna merah umbi ini tidak memiliki pigmen merah (antosianin). Rata-rata umbi bit mengandung pigmen betalain sebesar $1000 \mathrm{mg} / 100 \mathrm{~g}$ berat kering atau $120 \mathrm{mg} / 100 \mathrm{~g}$ berat basar (Andarwulan, 2012).

Dalam penelitian ini akan dibuat es krim nabati yang berbahan dasar sari kacang kedelai dikombinasikan dengan bubur umbi bit sebagai pewarna alami. Untuk memenuhi kandungan lemak pada es krim nabati maka dilakukan penambahan santan, sehingga kandungan gizi pada es krim terpenuhi.

Santan kelapa merupakan produk yang kaya akan zat gizi serta bahan bakunya sangat mudah didapatkan di Indonesia. Santan kelapa banyak digunakan sebagai sumber lemak nabati pada bahan makanan yang berlemak tinggi (Mahfud, 2005).

Santan kelapa merupakan produk yang kaya akan zat gizi serta bahan bakunya sangat mudah didapat di Indonesia. Santan kelapa banyak digunakan sebagai sumber lemak nabati pada bahan makanan yang berlemak tinggi. Penggantian bahan baku utama dari lemak susu menjadi lemak nabati yang berasal dari santan kelapa tidak dilakukan secara keseluruhan karena dikhawatirkan akan merubah tekstur, rasa dan kelembutan dari es krim. Lemak dalam pembuatan es krim dapat meningkatkan cita rasa pada es krim, menghasilkan tekstur yang lembut, membantu memberi bentuk pada es krim, dan membantu sifat leleh yang baik (Suharyanto, 2009).

\section{Metode Penelitian}

Bahan-bahan yang digunakan kacang kedelai, umbi bit, santan, sukrosa, CMC, dan Gum Xanthan.

Bahan-bahan yang digunakan untuk analisis kimia (kadar lemak, kadar protein) adalah garam kjedahl, $\mathrm{H}_{2} \mathrm{SO}_{4}$ pekat, $\mathrm{NaOH} 35 \%, \mathrm{Na}_{2} \mathrm{~B}_{4} \mathrm{O}_{7}, \mathrm{HCl} 0,1049 \mathrm{~N}$, larutan $\mathrm{N}-H e x a n e$ dan aquadest.

Alat-alat yang digunakan dalam pembuatan es krim adalah saringan, spatula kayu, kompos gas merk Rinnai, timbangan digital merk TANITA, blender merk Philips, mixer merk Philips, ice cream maker merk Sico, mangkok plastik, refraktometer merk ATAGO, labu kjeldahl, Erlenmeyer $250 \mathrm{ml}$ merk Pyrex, Destilator (Kjeltec $^{\mathrm{TM}}$ 2100), buret, statif, labu soxhlet, eksikator, labu ukur $50 \mathrm{ml}, 100 \mathrm{ml}$ merk Pyrex, batang pengaduk, oven merk Memmert, pipet ukur $25 \mathrm{ml}$ merk Iwaki, dan sentrifuse.

Penelitian yang akan dilakukan dibagi dalam dua tahap, yaitu penelitian pendahuluan dan penelitian utama.

Penelitian pendahuluan yang dilakukan yaitu menentukan perbandingan kacang kedelai dengan air untuk ektraksi, yaitu 1:4, 1:6 dan 1:8 dimana berat kacang kedelai tetap dan jumlah air yang berbeda-beda. Kemudian dilakukan uji total padatan terlarut pada sari kacang kedelai dengan menggunakan metode refraktometer dan total padatan terlarut yang paling tinggi yang pilih. Pembuatan bubur umbi bit dan santan dengan perbandingan 1:2 dimana berat air matang dua kali dari berat umbi bit dan kelapa.

Penelitian utama yang dilakukan adalah pembuatan es krim nabati dengan menggunakan sari kacang kedelai yang memiliki total padatan terlarut paling tinggi. Penelitian ini akan menentukan perbandingan sari kacang kedelai dengan sari umbi bit dengan santan. Penelitian utama terdiri dari rancangan perlakuan, rancangan respon, rancangan analisis, dan rancangan respon.

\section{Hasil dan Pembahasan \\ Hasil Penelitian Pendahuluan}

Penelitian pendahuluan yang dilakukan yaitu menentukan perbandingan air dan bahan baku, yaitu kacang kedelai. Variasi perbandingan kacang kedelai dengan air yang dilakukan dalam pembuatan sari kacang kedelai, yaitu (1:4), (1:6), dan (1:8). Sari kacang kedelai yang dihasilkan kemudian akan diuji total padatan terlarut dapat dilihat pada Tabel 1.

Tabel 1. Hasil Total Padatan Terlarut pada Sari Kacang Kedelai

\begin{tabular}{|c|c|}
\hline Perbandingan & Total Padatan Terlarut \\
\hline $1: 4$ & $12,36^{\circ}$ Brix \\
\hline $1: 6$ & $8,36^{\circ}$ Brix \\
\hline $1: 8$ & $5,35^{\circ}$ Brix \\
\hline
\end{tabular}

Berdasarkan Tabel 9 perbandingan kacang kedelai dengan air $1: 4$ yaitu $12,36^{\circ}$ Brix, $1: 6$ yaitu $8,36^{\circ}$ Brix dan $1: 8$ yaitu $5,35^{\circ}$ Brix. Dan sari kacang kedelai yang digunakan dalam pembuatan es krim nabati adalah sari kacang kedelai dengan perbandingan kacang kedelai dan air (1:4) karena memiliki nilai total padatan paling tinggi.

Hal ini menunjukan semakin besar air yang ditambahkan memperlihatkan total padatan pada sari kacang kedelai semakin kecil. Hal ini karenakan total padatan dalam sari kacang kedelai semakin rendah.

Menurut Yuwono dan Susanto (2006) jika nilai perbandingan komposisi kedelai dan air besar (jumlah air sedikit) maka akan menghasilkan total padatan dan kadar protein susu kedelai yang tinggi tetapi dengan ekstraksi yang kurang sempurna. Total padatan susu kedelai juga ditentukan oleh komponen terlarut biji, yakni karbohidrat dan protein, terutama globulin yang ternyata bervariasi antar varietas.

Kecukupan kandungan total padatan es krim berfungsi untuk meningkatkan kekentalan adonan es krim, sehingga mempertahankan kestabilan gelembung udara (Widiantoko et al., 2014). Total padatan yang terlalu rendah akan mengakibatkan tekstur es krim menjadi kasar dan apabila total padatan terlalu tinggi maka es krim akan menjadi lembek dan lengket. Total padatan menggantikan jumlah air yang ada dalam adonan. Semakin tinggi total padatan maka semakin kecil jumlah air yang ditambahkan dalam pembuatan es krim, sehingga dapat mengurangi kristal es yang terbentuk (Marshall et al, 2004). 


\section{Hasil Penelitian Utama}

Penelitian utama yang dilakukan adalah membuat es krim nabati dengan perbandingan sari kacang kedelai dengan konsentrasi santan. Respon penelitian utama produk es krim nabati ini adalah respon kimia meliputi kadar lemak dan kadar protein. Respon fisik yaitu meliputi overrun dan waktu leleh. Respon organoleptik dengan metode uji hedonik terhadap warna, aroma, rasa, dan tekstur.

\section{Kadar Lemak}

Berdasarkan Hasil Analisis Variasi (ANAVA) terhadap kadar lemak es krim nabati menunjukan bahwa perbandingan sari kacang kedelai dengan bubur umbi bit dan konsentrasi santan berpengaruh nyata terhadap respon kimia dalam atribut kadar lemak. Data hasil penelitian dapat dilihat pada Tabel 2 .

Tabel 2. Pengaruh Perbandingan Sari Kacang Kedelai dengan Bubur Umbi Bit terhadap Respon Kimia Atribut Kadar Lemak (\%) Es Krim Nabati

\begin{tabular}{|c|c|c|}
\hline $\begin{array}{c}\text { Perbandingan } \\
\text { Sari Kacang } \\
\text { Kedelai dengan } \\
\text { Bubur Umbi } \\
\text { Bit (A) }\end{array}$ & $\begin{array}{c}\text { Rata-rata } \\
\text { Perlakuan (\%) }\end{array}$ & $\begin{array}{c}\text { Taraf } \\
\text { Nyata }\end{array}$ \\
\hline a1 (1:1) & 4,50 & $\mathrm{~b}$ \\
\hline a2 (1:2) & 4,19 & $\mathrm{ab}$ \\
\hline a3 (2:1) & 4,02 & $\mathrm{a}$ \\
\hline
\end{tabular}

Keterangan : Huruf yang berbeda pada kolom taraf nyata menunjukan berbeda nyata berdasarkan uji lanjut Duncan 5\%.

Berdasarkan Tabel 2 menunjukan pengaruh perbandingan sari kacang kedelai dengan bubur umbi bit terhadap respon kimia atribut kadar lemak es krim nabati. Perbandingan sari kacang kedelai dengan bubur umbi bit 1:1 (a1) memiliki nilai rata-rata tertinggi yaitu 4,50, tingkat kadar lemak es krim nabati menurun pada perbandingan sari kacang kedelai dengan bubur umbi 1:2 (a2) yang memiliki nilai rata-rata 4,19 dan perbandingan sari kacang kedelai dengan bubur umbi 2:1 (a3) yang memiliki nilai rata-rata 4,02. Lemak yang terkandung dalam es krim nabati berasal dari bahan-bahan yang digunakan dan lemak tertinggi terdapat pada 1:1 (a1).

Lemak merupakan komponen utama yang penting di dalam es krim. Penggunaan dalam jumlah yang sesuai adalah hal yang penting untuk diperhatikan, tidak hanya bagi keseimbangan sifat-sifat campuran tetapi juga untuk memenuhi persyaratan minimal yang telah ditetapkan (Arbuckle,1986). Lemak dalam es krim dapat memperbaiki tekstur atau meningkatkan kehalusan es krim yang dihasilkan (Potter,1987). Lemak dalam es krim juga akan mempengaruhi sifat fisik overrun (volume pengembangan es krim). Menurut Bennion dan Hughes (1975), proses mixing mengakibatkan komponen-komponen lemak menyebar dan membentuk jaringan di sekitar udara dan mengikat air. Proses mixing dilakukan di suhu rendah agar tidak terjadi kristalisasi lemak.

Semakin rendah penggunaan sari kacang kedelai dan semakin tinggi penggunaan bubur umbi bit maka kadar lemak yang dihasilkan semakin menurun. Umbi bit mengandung lemak yang lebih kecil dibandingkan dengan sari kacang kedelai. Hal ini sesuai dengan Astawan (2004) dalam $100 \mathrm{~g}$ bahan susu kedelai mengandung 2,0 g lemak. Sedangkan umbi bit mengandung $0,1 \mathrm{~g}$ (Rubatzky, 2001).

Menurut Arbuckle (1986), kadar lemak didalam es krim komersial umumnya adalah 10-12\%, sedangkan menurut SNI No.01-3713-1995 kandungan lemak pada es krim minimal 5,0\% b/b. Kadar lemak pada pembuatan es krim nabati dengan perbandingan sari kacang kedelai degan bubur umbi bit dan konsentrasi santan ini berkisar $3,78 \%-4,89 \%$, sehingga belum memenuhi dalam SNI No.01-3713-1995.

\section{Kadar Protein}

Berdasarkan hasil Analisis Variansi (ANAVA) terhadap kadar proteim menunjukkan bahwa perbandingan sari kacang kedelai dengan bubur umbi bit dan konsentrasi santan yang digunakan maupun interaksi antara perbandingan sari kacang kedelai dengan bubur umbi bit dan konsentrassi santan tidak berpengaruh nyata terhadap respon kimia dalam atribut kadar protein. Hasil penelitian menunjukkan bahwa nilai rata-rata tertinggi diperoleh pada perlakuan penambahan sari kacang kedelai dengan bubur umbi bit (2:1) dan santan $20 \%$ (a3b2), yaitu $18,68 \%$. Sementara nilai rata-rata perlakuan terendah diperoleh pada perlakuan penambahan sari kacang kedelai dengan bubur umbi bit (1:1) dan santan $22 \%$ (a1b3), yaitu 10,93\%.

Protein merupakan salah satu komponen penting yang harus ada dalam produk es krim. Adonan es krim merupakan sistem emulsi dimana keberadaan protein dalam sistem memegang peranan yang cukup besar. Ketika polimer protein bersinggungan dengan lapisan permukaan globula lemak, bagian hirofobik protein akan terserap dalam interface dan bagian hidofilik akan tetap berada dalam larutan. Proporsi bagian terserap dan terdistribusi dari protein ini berpengaruh terhadap kestabilan emulsi (Friberg, 1976).

Keunggulan protein pada susu kedelai adalah proteinnya tidak menimbulkan alergi dan mempunyai susunan asam amino essensial paling lengkap dibandingkan jenis kacang-kacangan lainnya serta mirip dengan susu sapi sehingga sangat baik digunakan sebagai pengganti susu sapi, terutama bagi yang alergi terhadap susu sapi dan penderita Lactore intolerance. Protein pada susu kedelai merupakan sumber protein nabati yang sangat tinggi kandungan Lisin, yaitu sekitar 2300 gr/ 100 gr bahan (Astawan, 2004).

Kadar protein es krim nabati dengan perbandingan sari kacang kedelai dengan bubur umbi bit dan konsentrasi santan berkisar antara 10,93\% - 18,68\%. Berdasarkan kandungan proteinnya, es krim nabati 
dengan perbandingan sari kacang kedelai dengan bubur umbi bit dan konsentrasi santan dengan berbagai konsentrasi telah memenuhi persyaratan SNI No. 013713-1995, yaitu kandungan proteinnya minimal 2,7\%.

\section{Overrun}

Berdasarkan Hasil Analisis Variasi (ANAVA) terhadap overrun es krim nabati menunjukan bahwa perbandingan sari kacang kedelai dengan bubur umbi bit dan konsentrasi santan berpengaruh nyata terhadap respon fisik dalam atribut overrun. Data hasil penelitian dapat dilihat pada Tabel 3 .

Tabel 3. Pengaruh Perbandingan Sari Kacang Kedelai dengan Bubur Umbi Bit terhadap Respon Fisik Atribut Overrun (\%) Es Krim Nabati.

\begin{tabular}{|c|c|c|}
\hline $\begin{array}{c}\text { Perbandingan Sari } \\
\text { Kacang Kedelai } \\
\text { dengan Bubur } \\
\text { Umbi Bit (A) }\end{array}$ & $\begin{array}{c}\text { Rata-rata } \\
\text { Perlakuan }\end{array}$ & Taraf Nyata \\
\hline a1 (1:1) & 34,13 & b \\
\hline a2 (1:2) & 25,00 & a \\
\hline a3 (2:1) & 40,08 & c \\
\hline
\end{tabular}

Keterangan : Huruf yang berbeda pada kolom taraf nyata menunjukan berbeda nyata berdasarkan uji lanjut Duncan 5\%.

Berdasarkan Tabel 3 menunjukan pengaruh perbandingan sari kacang kedelai dengan bubur umbi bit terhadap respon fisik atribut overrun es krim nabati. Perbandingan sari kacang kedelai dengan bubur umbi bit 2:1 (a3) memiliki nilai rata-rata tertinggi yaitu 40,08, tingkat overrun es krim nabati menurun pada perbandingan sari kacang kedelai dengan bubur umbi 1:2 (a2) yang memiliki nilai rata-rata 34,13 dan perbandingan sari kacang kedelai dengan bubur umbi 1:1 (a1) yang memiliki nilai rata-rata 25,00. Hal ini dikarenakan semakin banyak sari kacang kedelai ditambahkan maka overrun pada es krim semakin besar dan didapat dari perbandingan sari kacang kedelai dengan bubur umbi bit 2:1 (a3).

Overrun mencerminkan kemampuan pembentukan buih dan kemantapan buih yang berkaitan dengan penurunan tegangan permukaan pada sistem yang terdiri atas udara dan air yang disebabkan oleh adsorpsi molekul protein (Sathe et al., 1982). Semakin banyak penambahan sari kacang kedelai maka overrun es krim yang dihasilkan semakin tinggi dan semakin banyak penambahan bubur umbi bit maka overrun es krim yang dihasilkan semakin rendah.

Menurut Arbuckle dan Marshall (1996) menyatakan bahwa adonan yang kental akan menyebabkan overrun rendah, karena adonan mengalami kesulitan untuk mengembang dan udara sulit menembus masuk permukaan adonan. Overrun juga sangat dipengaruhi oleh protein yang ada pada es krim. Semakin rendah kadar protein, semakin sulit adonan es krim mengembang sehingga overrun es krim semakin rendah.

Hal ini sesuai dengan dengan pendapat Padaga dan Sawitri (2006) yang menyatakan bahwa protein akan mempengaruhi overrun. Unsur protein dalam pembuatan es kim berfungsi untuk menstabilkan emulsi lemak setelah proses homogenisasi, membantu pembuihan, meningkatkan dan menstabilkan daya ikat air yang berpengaruh pada kekentalan dan tekstur es krim yang lembut juga dapat meningkatkan nilai overrun es krim.

\section{Waktu Leleh}

Berdasarkan Hasil Analisis Variasi (ANAVA) terhadap waktu leleh es krim nabati menunjukan bahwa perbandingan sari kacang kedelai dengan bubur umbi bit dan konsentrasi santan berpengaruh nyata terhadap respon fisik dalam atribut waktu leleh. Data hasil penelitian dapat dilihat pada Tabel 4.

Tabel 4. Pengaruh Perbandingan Sari Kacang Kedelai dengan Bubur Umbi Bit terhadap Respon Fisik Atribut Waktu Leleh (menit) Es Krim Nabati

\begin{tabular}{|c|c|c|}
\hline $\begin{array}{c}\text { Perbandingan Sari } \\
\text { Kacang Kedelai } \\
\text { dengan Bubur } \\
\text { Umbi Bit (A) }\end{array}$ & $\begin{array}{c}\text { Rata-rata } \\
\text { Perlakuan } \\
\text { (Menit) }\end{array}$ & Taraf Nyata \\
\hline a1 (1:1) & 23,87 & a \\
\hline a2 (1:2) & 26,94 & b \\
\hline a3 (2:1) & 22,91 & a \\
\hline
\end{tabular}

Keterangan : Huruf yang berbeda pada kolom taraf nyata menunjukan berbeda nyata berdasarkan uji lanjut Duncan 5\%.

Berdasarkan Tabel 4 menunjukan pengaruh perbandingan sari kacang kedelai dengan bubur umbi bit terhadap respon fisik atribut waktu leleh es krim nabati. Perbandingan sari kacang kedelai dengan bubur umbi bit 1:2 (a2) memiliki nilai rata-rata tertinggi yaitu 26,94 , tingkat waktu leleh es krim nabati menurun pada perbandingan sari kacang kedelai dengan bubur umbi 1:1 (a1) yang memiliki nilai rata-rata 23,87 dan perbandingan sari kacang kedelai dengan bubur umbi 2:1 (31) yang memiliki nilai rata-rata 22,91. Hal ini dikarenakan Hal ini dikarenakan semakin banyak bubur umbi bit ditambahkan maka waktu leleh pada es krim semakin lama didapat dari perbandingan sari kacang kedelai dengan bubur umbi bit 1:2 (a2).

Semakin tinggi penggunaan bubur umbi bit dan semakin rendah penggunaan sari kacang kedelai kecepatan leleh es krim semakin lama. Hal ini disebabkan karena sari umbi bit lebih banyak karbohidrat dibandingkan dengan sari kacang kedelai sehingga adonan semakin kental. Karbohidrat merupakan senyawa yang memiliki kemampuan mengikat air yang tinggi karena bersifat hidrofilik (Susilawati, 2014).

Waktu leleh berkaitan dengan tinggi rendahnya overrun, semakin tinggi overrun maka semakin cepat es krim meleleh, begitu sebaliknya. Penambahan sari kacang kedelai yang mengandung protein tinggi akan menyebabkan overrun es krim semakin baik namun mengakibatkan es krim menjadi lebih mudah mencair. Pernyataan tersebut diperkuat oleh penelitian Oksilia dan Lindasari (2012), Penambahan sari kedelai yang tinggi protein akan menyebabkan pembuihan es krim semakin 
baik dan akan meningkatkan volume es krim yang menyebabkan waktu pelelehan semakin cepat.

5. Uji Organoleptik

Respon organoleptik dilakukan terhadap atribut warna, aroma, rasa, dan tekstur dengan skala nilai 1 (sangat tidak suka), 2 (tidak suka), 3 (agak tidak suka), 4 (agak suka), 5 (suka), 6 (sangat suka).

\section{Warna}

Berdasarkan Hasil Analisis Variasi (ANAVA) terhadap warna es krim nabati menunjukan bahwa perbandingan sari kacang kedelai dengan bubur umbi bit dan konsentrasi santan berpengaruh nyata terhadap respon organoleptik dalam atribut warna. Data hasil penelitian dapat dilihat pada Tabel 5.

Tabel 5. Pengaruh Perbandingan Sari Kacang Kedelai dengan Bubur Umbi Bit terhadap Respon Organoleptik Atribut Warna Es Krim Nabati

\begin{tabular}{|c|c|c|}
\hline $\begin{array}{c}\text { Perbandingan Sari } \\
\text { Kacang Kedelai } \\
\text { dengan Bubur } \\
\text { Umbi Bit (A) }\end{array}$ & $\begin{array}{c}\text { Rata-rata } \\
\text { Perlakuan }\end{array}$ & Taraf Nyata \\
\hline a1 (1:1) & 4,57 & a \\
\hline a2 (1:2) & 5,09 & b \\
\hline a3 (2:1) & 4,70 & a \\
\hline
\end{tabular}

Keterangan : Huruf yang berbeda pada kolom taraf nyata menunjukan berbeda nyata berdasarkan uji lanjut Duncan $5 \%$.

Berdasarkan Tabel 5 menunjukan pengaruh perbandingan sari kacang kedelai dengan bubur umbi bit terhadap respon organoleptik atribut warna es krim nabati. Perbandingan sari kacang kedelai dengan bubur umbi bit 1:2 (a2) memiliki nilai rata-rata tertinggi yaitu 4,57 , tingkat penilaian panelis terhadap warna menurun pada perbandingan sari kacang kedelai dengan bubur umbi 2:1 (a3) yang memiliki nilai rata-rata 4,70 dan perbandingan sari kacang kedelai dengan bubur umbi 1:1 (a1) yang memiliki nilai rata-rata 5,09. Hal ini dikarenakan panelis tidak menyukai warna yang berwarna ungu pucat, panelis lebih menyukai es krim nabati dengan warna ungu cerah yang didapat dari perbandingan sari kacang kedelai dengan bubur umbi bit $1: 2$ (a2).

Hal tersebut disebabkan semakin tinggi penggunan bubur umbi bit maka warna es krim yang dihasilkan akan semakin berwarna merah keunguan. Widyianingrum dan Suhartiningsih (2014) mengatakan bahwa warna merah keunguan disebabkan oleh kandungan pigmen yang berasal dari bubur umbi bit yang digunakan. Bit merupakan sejenis umbi-umbian yang memiliki warna yang spesifik, yaitu merah keunguan yang pekat, merah keunguan pada bit disebabkan adanya gabungan dua pigmen yaitu antara pigmen ungu betasianin dan pigmen kuning betaxanin. Menurut Soekarto (2002) warna mempunyai arti dan peranan yang sangat penting pada komoditas pangan dan hasil-hasil pertanian lainnya.

Pemberian pewarna alami dari bit memberikan warna merah keunguan pada es krim nabati yang disebabkan adanya pigmen betalain. Warna merah keunguan ini lebih menarik sehingga diminati dan merupakan inovasi dalam pembuatan es krim nabati.

\section{Aroma}

Berdasarkan Hasil Analisis Variasi (ANAVA) warna es krim nabati menunjukan bahwa perbandingan sari kacang kedelai dengan bubur umbi bit dan konsentrasi santan berpengaruh nyata terhadap respon organoleptik dalam atribut aroma. Data hasil penelitian dapat dilihat pada Tabel 6 .

Tabel 6. Pengaruh Perbandingan Sari Kacang Kedelai dengan Bubur Umbi Bit terhadap Respon Organoleptik Atribut Aroma Es Krim Nabati

Atribut Aroma Es Krim Nabati
\begin{tabular}{|c|c|c|}
\hline $\begin{array}{c}\text { Perbandingan Sari } \\
\text { Kacang Kedelai } \\
\text { dengan Bubur } \\
\text { Umbi Bit (A) }\end{array}$ & $\begin{array}{c}\text { Rata-rata } \\
\text { Perlakuan }\end{array}$ & Taraf Nyata \\
\hline a1 (1:1) & 3,98 & a \\
\hline a2 (1:2) & 4,31 & b \\
\hline a3 (2:1) & 4,48 & b \\
\hline
\end{tabular}

Keterangan : Huruf yang berbeda pada kolom taraf nyata menunjukan berbeda nyata berdasarkan uji lanjut Duncan 5\%.

Berdasarkan Tabel 6 menunjukan pengaruh perbandingan sari kacang kedelai dengan bubur umbi bit terhadap respon organoleptik atribut aroma es krim nabati. Perbandingan sari kacang kedelai dengan bubur umbi bit 1:1 (a1) memiliki nilai rata-rata tertinggi yaitu 3,98 , tingkat penilaian panelis terhadap aroma menurun pada perbandingan sari kacang kedelai dengan bubur umbi 1:2 (a2) yang memiliki nilai rata-rata 4,31 dan perbandingan sari kacang kedelai dengan bubur umbi 1:1 (a1) yang memiliki nilai rata-rata 4,48. Hal ini dikarenakan panelis tidak menyukai aroma langu dari kedelai, panelis lebih menyukai es krim nabati dengan aroma langu umbi bit yang didapat dari perbandingan sari kacang kedelai dengan bubur umbi bit 2:1 (a3).

Aroma es krim yang dihasilkan beraroma sari kacang kedelai hingga agak beraroma bubur umbi bit. Menurut Kartika et al (1988), penanganan dan penyimpanan suatu produk makanan dapat menentukan bau dari produk tersebut yang mana bau merupakan salah satu faktor penentu kualitas produk makanan. Dalam industri pangan pengujian aroma atau bau dianggap penting karena dapat menentukan diterima atau tidaknya produk tersebut. Timbulnya aroma atau bau ini karena zat bau tersebut bersifat volatil (mudah menguap) (Demann, 1989).

Aroma pada es krim bukan merupakan penentu kualitas yang utama, tetapi tetap merupakan parameter yang penting. Dengan semakin bertambahnya konsentrasi susu kedelai menyebabkan aroma yang dihasilkan dari es krim menjadi sedikit langu (beany flavor). Hal ini disebabkan aroma es krim lebih banyak dipengaruhi oleh sumber lemak yang digunakan (Arbuckle, 1972). Sesuai dengan Hartoyo (2000), bahwa saat ekstraksi dan memasak biji dapat menonaktifkan 
enzim lipoksigenase yang terdapat pada biji-bijian yang dapat menimbulkan bau langu.

Pada dasarnya bit memiliki bau yang langu, namun pada proses pembuatan sari bit, bit dikukus sehingga dapat menghilangkan bau langu. Sesuai dengan Astawan (2009) bahwa bau langu dapat hilang ketika terkena suhu panas atau proses pemasakan dengan suhu tinggi. Semakin tinggi penggunaan sari bit pada pembuatan es krim nabati maka es krim yang dihasilkan akan semakin beraroma tanah. Hal ini dikarenakan semakin tinggi penggunaan bubur umbi bit maka aroma langu sari kedelai akan berkurang dan semakin beraroma bit dan sebaliknya. Hal ini disebabkan bubur umbi bit mengandung senyawa geosmin yang menyebabkan aroma es krim berbau seperti tanah (Liana, 2017).

\section{Rasa}

Berdasarkan Hasil Analisis Variasi (ANAVA) terhadap tekstur es krim nabati menunjukan bahwa perbandingan sari kacang kedelai dengan bubur umbi bit dan konsentrasi santan berpengaruh nyata terhadap respon organoleptik dalam atribut rasa. Data hasil penelitian dapat dilihat pada Tabel 7 .

Tabel 7. Pengaruh Interaksi Perbandingan Sari Kacang Kedelai dengan Bubur Umbi Bit dan Konsentrasi Santan terhadap Respon Organoleptik Atribut Rasa Es Krim Nabati

\begin{tabular}{|c|c|c|c|}
\hline \multirow[b]{2}{*}{$\begin{array}{c}\text { Perbandingan } \\
\text { Sari Kacang } \\
\text { Kedelai dengan } \\
\text { Bubur Umbi Bit } \\
\text { (A) }\end{array}$} & \multicolumn{3}{|c|}{ Konsentrasi Santan } \\
\hline & $\begin{array}{c}\mathrm{b} 1 \\
(18 \%)\end{array}$ & $\begin{array}{c}\mathrm{b} 2 \\
(20 \%)\end{array}$ & $\begin{array}{c}\text { b3 } \\
(22 \%)\end{array}$ \\
\hline a1 $(1: 1)$ & $\begin{array}{c}\mathrm{A} \\
4,00 \\
\mathrm{a}\end{array}$ & $\begin{array}{c}\mathrm{A}_{4,24} \\
\mathrm{ab}\end{array}$ & $\begin{array}{c}\mathrm{A}_{4,37} \\
\mathrm{~b}\end{array}$ \\
\hline a2 (1:2) & $\begin{array}{c}3^{\mathrm{A}} \\
\mathrm{a}^{\mathrm{a}}\end{array}$ & $\begin{array}{c}\mathrm{A}_{4,27} \\
\mathrm{~b}\end{array}$ & $\begin{array}{c}{ }_{4,60} \\
c^{B}\end{array}$ \\
\hline a3 (2:1) & $\begin{array}{c}4^{4,73} \\
\mathrm{a}\end{array}$ & $\begin{array}{c}4^{4,93} \\
\text { b }\end{array}$ & $\begin{array}{c}{ }_{5,50} \mathrm{C} \\
\mathrm{c}\end{array}$ \\
\hline
\end{tabular}

Keterangan : Setiap huruf yang berbeda menunjukan adanya perbedaan yang nyata pada taraf 5\%. Uji Duncan (huruf kecil dibaca secara horizontal dan huruf besar besar secara vertikal).

Berdasarkan data Tabel 7 menunjukkan bahwa interaksi antara perbandingan sari kacang kedelai dengan bubur umbi bit dan konsentrasi santan menghasilkan perbedaan nyata terhadap rasa es krim nabati. Semakin tinggi konsentrasi santan yang ditambahkan maka tingkat kesukaan panelis terhadap rasa dari es krim nabati semakin meningkat. Nilai tertinggi es krim nabati yang disukai panelis pada perbandingan sari kacang kedelai dengan bubur bit (2:1) dan konsentrasi santan 22\% (a3b3) yaitu 5,50, sedangkan nilai nilai terendah terhadap es krim nabati pada perbandingan sari kacang kedelai dengan bubur bit (1:2) dan konsentrasi santan 18\% (a2b1) yaitu 3,89. Semakin banyak konsentrasi santan yang ditambahkan maka kesukaan panelis terhadap rasa es krim nabati semakin meningkat. Hal ini sesuai dengan pendapat Fachrudin (1997), bahwa penambahan santan dalam pengolahan makanan dapat menambahkan cita rasa dan nilai gizi produk pangan yang dihasilkan.

Menurut Padaga (2005), rasa sangat mempengaruhi kesukaan konsumen terhadap es krim, bahkan dapat dikatakan merupakan faktor penentu utama. Menurut Eckles (1984) penerimaan es krim sangat tergantung dari cita rasanya. es krim yang mencair akan terasa sangat manis dibandingkan dalam keadaan beku (Winarno, 2002).

Semakin tinggi penggunaan bit, maka rasa yang dihasilkan akan semakin berasa umbi bit. Semakin tinggi penggunaan umbi bit citarasa langu dari sari kedelai mulai berkurang seiring dengan penambahan umbi bit. Hal ini berarti penggunaan umbi bit maupun sari kacang kedelai berpengaruh terhadap rasa es krim yang dihasilkan (Liana, 2017). Hal ini di dukung oleh Padaga dan Sawitri (2005) yang menyatakan rasa yang dihasilkan pasa es krim tersebut dipengaruhi oleh bahanbahan yang digunakan.

\section{Tekstur}

Berdasarkan Hasil Analisis Variasi (ANAVA) tekstur es krim nabati menunjukan bahwa perbandingan sari kacang kedelai dengan bubur umbi bit dan konsentrasi santan berpengaruh nyata terhadap respon organoleptik dalam atribut tekstur. Data hasil penelitian dapat dilihat pada Tabel 8.

Tabel 8. Pengaruh Perbandingan Sari Kacang Kedelai dengan Bubur Umbi Bit terhadap Respon Organoleptik Atribut Tekstur Es Krim Nabati

\begin{tabular}{|c|c|c|}
\hline $\begin{array}{c}\text { Perbandingan Sari } \\
\text { Kacang Kedelai } \\
\text { dengan Bubur } \\
\text { Umbi Bit (A) }\end{array}$ & $\begin{array}{c}\text { Rata-rata } \\
\text { Perlakuan }\end{array}$ & Taraf Nyata \\
\hline a1 (1:1) & 4,56 & $\mathrm{a}$ \\
\hline a2 (1:2) & 4,71 & $\mathrm{~b}$ \\
\hline a3 (2:1) & 4,84 & $\mathrm{c}$ \\
\hline
\end{tabular}

Keterangan : Huruf yang berbeda pada kolom taraf nyata menunjukan berbeda nyata berdasarkan uji lanjut Duncan 5\%.

Berdasarkan Tabel 8 menunjukan pengaruh perbandingan sari kacang kedelai dengan bubur umbi bit terhadap respon organoleptik atribut tekstur es krim nabati. Perbandingan sari kacang kedelai dengan bubur umbi bit 1:1 (a1) memiliki nilai rata-rata tertinggi yaitu 4,56 , tingkat penilaian panelis terhadap aroma menurun pada perbandingan sari kacang kedelai dengan bubur umbi 1:2 (a2) yang memiliki nilai rata-rata 4,71 dan perbandingan sari kacang kedelai dengan bubur umbi 1:1 (a1) yang memiliki nilai rata-rata 4,84. Hal ini dikarenakan panelis tidak menyukai tekstur yang tinggi kandungan kedelai, panelis lebih menyukai es krim nabati dengan tekstur yang tinggi kandungan umbi bit 
yang didapat dari perbandingan sari kacang kedelai dengan bubur umbi bit 2:1 (a3).

Tabel 9. Pengaruh Konsentrasi Santan terhadap Respon Organoleptik Atribut Tekstur Es Krim Nabati

\begin{tabular}{|c|c|c|}
\hline $\begin{array}{c}\text { Konsentrasi } \\
\text { Santan (B) }\end{array}$ & $\begin{array}{c}\text { Rata-rata } \\
\text { Perlakuan }\end{array}$ & Taraf Nyata \\
\hline b1 (18\%) & 4,63 & a \\
\hline b2 (20\%) & 4,67 & a \\
\hline b3 (22\%) & 4,82 & b \\
\hline
\end{tabular}

Keterangan : Huruf yang berbeda pada kolom taraf nyata menunjukan berbeda nyata berdasarkan uji lanjut Duncan 5\%.

Berdasarkan Tabel 14 menunjukan konsentrasi santan terhadap respon organoleptik atribut tekstur es krim nabati. Konsentrasi santan $18 \%$ (b1) memiliki nilai ratarata tertinggi yaitu 4,63, tingkat penilaian panelis terhadap aroma menurun pada konsentrasi santan $20 \%$ (b2) yang memiliki nilai rata-rata 4,67 dan konsentrasi santan $22 \%$ (b3) yang memiliki nilai rata-rata 4,82. Hal ini dikarenakan panelis tidak menyukai tekstur yang tinggi kandungan santan, panelis lebih menyukai es krim nabati dengan tekstur yang tinggi kandungan santan yang didapat dari konsentrasi santan $22 \%$ (a3).

Tekstur es krim yang ideal adalah yang ukuran partikel padatannya sangat kecil, sehingga tidak terdeteksi di dalam mulut (Arbuckle, 1986). Tekstur secara umum diartikan sebagai persepsi dan sifat dari produk setelah dipegang dan dimakan (Rosenthal, 1999).

Semakin kecil penambahan sari kacang kedelai dan semakin tinggi penggunaan bubur umbi bit dan penggunaan santan maka tekstur es krim yang dihasilkan akan semakin lembut. Suprayitno (2001) semakin lembutnya es krim yang dihasilkan dipengaruhi oleh globula lemak dan gelembung-gelembung udara yang terperangkap di dalam adonan es krim. Ismunandar (2004) menjelaskan bahwa lemak berfungsi memberikan tekstur yang halus, berkontribusi dengan rasa serta memberikan aspek sinergis dengan flavor yang ditambahkan dan memperindah penampakan.

Tekstur es krim ditentukan oleh padatan yang terkandung dalam adonan. Padatan tersebut dapat berasal dari karbohidrat, padatan susu tanpa lemak, dan protein. Tekstur es krim secara langsung berkaitan dengan struktur. Struktur tergantung pada ukuran, jumlah dan susunan udara sel, kristal es, kristal laktosa dan gumpalan lemak. Tekstur halus merupakan indikator sel-sel udara pada es krim kecil dan seragam serta tidak ada kristal (Abdullah et al., 2003). Abdullah et al. (2003) menambahkan bahwa tekstur es krim terbentuk selama penyimpanan, terutama ketika es krim berada di freezer. Menurut Padaga dan Sawitri (2005), tekstur lembut es krim sangat dipengaruhi oleh komposisi ICM, cara mengolah, dan kondisi penyimpanan.

Berdasarkan penelitian yang telah dilakukan dapat diambil kesimpulan sebagai berikut:

Penelitian pendahuluan menghasilkan total padatan terlarut sebesar $12,36 \%$ dengan perbandingan air dan kacang kedelai 1 : 4., Perbandingan sari kacang kedelai dengan bubur umbi bit berpengaruh terhadap respon fisik meliputi overrun dan waktu leleh, berpengaruh terhadap respon kimia meliputi kadar lemak dan berpengaruh terhadap respon organoleptik meliputi atribut warna, aroma dan tekstur, Konsentrasi santan berpengaruh terhadap respon organoleptik atribut tekstur, Perbandingan sari kacang kedelai dengan bubur umbi bit dan konsentrasi santan serta interaksi perbandingan sari kacang kedelai dengan bubur umbi bit dan konsentrasi santan berpengaruh terhadap respon organoleptik meliputi atribut rasa.

\section{Daftar Pustaka}

1. Arbuckle, W. S. and R. T. Marshall. (1996). Ice Cream : 2th Edition. Chapman and Hall. New York.

2. Astawan, M. (2004). Tetap Sehat dengan Produk Makanan Olahan. Tiga Serangkai. Solo.

3. deMann, M. J. (1989). Kimia Makanan. Penerjemah : K. Padmawinata. ITB-Press, Bandung.

4. Fachrudin. (1997). Membuat Aneka Selai. Kanilius, Yogyakarta.

5. Friberg, E. S. (1976). Food Emulsions. Marcel Dekker Inc. New York.

6. Hartoyo, B. (2005). Perbaikan Mutu Susu Kedelai di dalam Botol. Bandung: Departemen Perindustrian. Bogor.

7. Ismunandar. (2004). Dibalik Lembutnya Es Krim. Departemen Kimia. FMIFA ITB. Bogor.

8. Kartika, B. P. Hastuti dan W. Suprapto. (1988). Pedoman Uji Indrawi Bahan Pangan. Proyek Pembangunan Pusat Fasilitas Bersama Antar Universitas Pangan dan Gizi. Univesitas Gadjah Mada. Yogyakarta.

9. Liana, D. F., Ayu dan Rahmayuni. (2017). Pemanfaatan Susu Kedelai dan Ekstrak Umbi Bit dalam Pembuatan Es Krim. Jurnal. Program Teknologi Pertanian. Fakultas Pertanian. Universitass Riau.

10. Padaga, M dan Sawitri. (2005). Membuat Es Krim yang Sehat. Trubus Agrisarana. Surabaya.

11. Potter, N. N. (1978). Food Science. The AVI Publishing Company, Inc. Westport. Connecticut.

12. Sathe, S. K., Deshpande, S. S and Salunkhe, D. K. (1982). Functional properties of winged bean (Psophocarpus tetragonolobus, L) proteins. Journal o Food Science 47: 503-506.

13. Susilawati, F., Nuriny dan A. w. Nugraha. (2014). Pengaruh Penambahan Ubi Jalar Ungu terhadap Sifat Organoleptik Es Krim Susu Kambing Peranakan Etawa. Jurnal Teknologi dan Industri Pertanian. Fakultas Pertanian. Universitas Lampung.

14. Widiantoko, R. K dan Yunianta. (2014). Pembuatan Es Krim Tempe Jahe (Kajian Proporsi Bahan dan Penstabil terhadap Sifat Fisik, Kimia dan Organoleptik). Jurnal Pangan dan Agriindustri 2(1): 54-66. 
15. Widyaningrum, M. L. dan Suhartiningsih. (2014).

Pengaruh Penambahan Puure Bit (Beta vulgaris) terhadap Sifat Organoleptik Kerupuk. E-Journal Boga, 3 (1): 233-238.

16. Yuwono, S. S dan Susanto, T. (2006). Pengaruh Perbandingan Kedelai: Air pada Proses Ektraksi terhadap Ekstraktabilitas Padatan, Protein dan Kalsium Kedelai serta Rasio Fraksi Protein 7s/11s. Jurnal Teknologi. 